\title{
Critical pulmonary stenosis with prenatal diagnosis: a case series and review of literature
}

\author{
Oya Demirci', Taner Yavuz², Resul Arısoy', Emre Erdoğdu', Pınar Kumru', Oya Pekin' \\ ${ }^{1}$ Perinatology Clinic, Zeynep Kamil Maternity and Pediatrics Training and Research Hospital, Istanbul, Turkey \\ ${ }^{2}$ Pediatric Cardiology Unit, Zeynep Kamil Maternity and Pediatrics Training and Research Hospital, Istanbul, Turkey
}

\begin{abstract}
Objective: The aim of the study is to investigate the morphology of right ventricular cavity, the tricuspid valve size and the treatments applied at postnatal period in cases with critical pulmonary stenosis (PS) having intact ventricular septum.

Methods: Seven cases included in the study who were considered to have critical PS in fetal echocardiography at second and third trimesters. The fetuses found to have antegrade jet stream at pulmonary valve level and reverse flow at ductus arteriosus as well as hyperthrophy and hypoplasia on the right ventricle were determined as critical PS. The cases were categorized as bipartite or tripartite according to the morphology of right ventricular cavity. Z-score of tricuspid valve was calculated according to the week of gestation.

Results: Bipartite right ventricle cavity was found in cases diagnosed at second trimester, and tripartite right ventricle cavity in cases diagnosed at third trimester. Tricuspid valve $Z$-score of the cases with bipartite right ventricle morphology was less than those with tripartite. Two out of seven cases were monochorionic diamniotic twin pregnancies. Balloon valvuloplasty was performed on postnatal second day despite the prostaglandin E1 (PGE1) infusion in 3 cases with bipartite, and 3 cases required Blalock-Taussing shunt. In four tripartite cases, cyanosis control was better by PGE1 infusion, and balloon valvuloplasty was performed on postnatal second day in 3 cases and on postnatal 55th day in 4 cases. No Blalock-Taussing shunt was required.

Conclusion: In critical PS cases, the treatment methods to be applied during postnatal period may vary according to the right ventricle being of two or three parts and the stenosis level of tricuspid valve.
\end{abstract}

Keywords: Critical pulmonary stenosis, tricuspid stenosis, tricuspid deficiency, postnatal treatment.

\section{Özet: Prenatal tanılı kritik pulmoner stenoz: Olgu serisi ve literatür derlemesi}

Amaç: Ventriküler septumu intakt olan kritik pulmoner stenozlu (PS) olgularda sağ ventrikül kavitesinin morfolojisi, triküspit kapak boyutu ve postnatal uygulanan tedavilerin değerlendirilmesi amaçlanmıştır.

Yöntem: Çalışmaya ikinci ve üçüncü trimestrede fetal ekokardiyografide kritik PS düşünülen 7 olgu alındı. Sağ ventrikülde hipertrofi ve hipoplazinin yanı sıra pulmoner kapak seviyesinde ileri yönde jet akım ve duktus arteriozusta ters akım saptanan fetüsler kritik PS olarak değerlendirildi. Sağ ventrikül kavitesinin morfolojisine göre olgular bipartit veya tripartit olarak ayrıldı. Gestasyon haftasına göre triküspit kapak Z-skoru hesaplandı.

Bulgular: İkinci trimesterde tanı konulan olgularda bipartit, üçüncü trimesterde tanı konulan olgularda tripartit sağ ventrikül kavitesi belirlendi. Bipartit sağ ventrikül morfolojili olguların triküspit kapak Z-skoru, tripartit olanlardan daha düşük olarak hesapland. Yedi olgunun ikisi monokoryonik diamniyotik ikiz gebelikti. Bipartit olan 3 olguda prostaglandin E1 (PGE1) infüzyonuna rağmen postnatal 2. günde balon valvüloplasti yapıldı ve 3 olguda da Blalock-Taussing şant gereksinimi oldu. Tripartit dört olguda ise PGE1 infüzyonu ile siyanoz kontrolü daha iyi sağlanmış, üç olguda postnatal 2. haftada, dördüncü olguda ise postnatal 55. günde balon valvüloplasti uygulandı. Blalock-Taussing şant gereksinimi olmadi.

Sonuç: Kritik PS olgularında sağ ventrikülün iki ya da üç parçalı olma durumuna, triküspit kapağın darlık derecesine bağlı olarak postnatal dönemdeki uygulanacak tedavi yöntemleri değişebilmektedir.

Anahtar sözcükler: Kritik pulmoner stenoz, triküspit darlık, triküspit yetmezlik, postnatal tedavi.
Correspondence: Oya Demirci, MD. Zeynep Kamil Kadın ve Çocuk Hastalıkları Eğitim ve Araştırma Hastanesi, Perinatoloji Kliniği, İstanbul, Turkey. e-mail: demircioya@gmail.com Received: October 27, 2014; Accepted: January 24, 2015

Please cite this article as: Demirci O, Yavuz T, Arısoy R, Erdoğdu E, Kumru P, Pekin O. Critical pulmonary stenosis with prenatal diagnosis: a case series and review of literature. Perinatal Journal 2015;23(1):34-38.

(92015 Perinatal Medicine Foundation
Available online at: www.perinataljournal.com/20150231008 doi: $10.2399 /$ prn. 15.0231008 QR (Quick Response) Code:

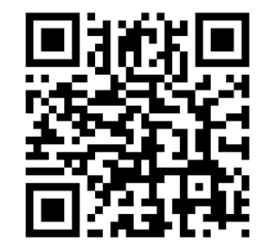




\section{Introduction}

Critical pulmonary stenosis (PS) causes reverse flow in the ductus arteriosus of fetus and severe right ventricular hypertrophy. Secondary to hypertrophy, the right ventricular cavity gets narrow especially at apex. During neonatal period, it causes shunt and cyanosis at interatrial level from right to left. Critical PS can also be evaluated within pulmonary atresia with intact ventricular septum (PAIVS) due to the fact that it may progress to pulmonary atresia $(\mathrm{PA})$ as week of gestation advances. ${ }^{[1]}$ The most distinguishing characteristic of the fetus with critical pulmonary stenosis from mild and medium PS is the reverse flow of ductus arteriosus seen in ultrasonographic examination. ${ }^{[1,2]}$ There is no concomitant genetic disease or extra cardiac anomaly in most of the PAIVS and critical PS cases. ${ }^{[1]}$ The abnormal appearance in quadrilocular during cardiac examination between 18 and 22 weeks of gestation at second trimester is usually the most striking characteristics and it initiates the process toward the diagnosis. However, although some cases have PS at critical levels, the sizes of right ventricle may seem normal and it may cause late diagnosis. In some other cases, PAIVS and critical PS diagnosis may be established even at the first trimester. ${ }^{[1]}$

Right ventricular cavity morphologically consists of three parts which are inlet, apex and outlet. Ventricular hyperthropy occurs at various levels depending on the size of narrowing of the right ventricular outlet and the week of gestation that pulmonary atresia occurs, stenosis on tricuspid valve and the level of failure. ${ }^{[1]}$ As a result of the overgrowth of intracavity muscular layer, apex of right ventricle (bipartite) or both apex and outlet (unipartite) may not develop. In critical PS, right ventricle usually has all three parts (tripartite). Sometimes, apical region may not develop well and may have bipartite morphology as in PAIVS. ${ }^{[1,2]} \mathrm{Z}$-score is used when evaluating tricuspid valve size. ${ }^{[1-3]}$ In cases which developed right ventricular hypoplasia with bipartite and unipartite morphology, severe tricuspid valve stenosis (low Z-score) is also observed. ${ }^{[1,2]}$

For newborns with critical pulmonary stenosis, various treatment options are offered according to right ventricular morphology usually at postnatal early period such as balloon valvuloplasty, ductal stent, BlalockTaussing (BT) shunt operation, biventricular repair at advanced periods, and Glenn or Fontan procedures. In our study, we aimed to investigate the morphology of right ventricular cavity, tricuspid valve $\mathrm{Z}$-scores and treatments applied in cases with critical pulmonary stenosis (PS) having intact ventricular septum.

\section{Methods}

Seven cases considered having critical PS in fetal echocardiography at second and third trimesters at the Perinatology Clinic of Zeynep Kamil Maternity and Pediatrics Training and Research Hospital between 2013 and 2014 were included in the study. The fetuses found to have antegrade jet stream at pulmonary valve level and reverse flow at ductus arteriosus as well as hyperthrophy and hypoplasia on the right ventricle were suspected to be critical PS. The cases with postnatal clinical progress and echocardiography findings compatible with critical PS were included in the study. The cases were categorized as bipartite or tripartite according to the morphology of right ventricular cavity. Zscore of tricuspid valve was calculated according to the week of gestation. ${ }^{[3]}$ Tricuspid valve insufficiency was categorized as mild, medium and severe. ${ }^{[4,5]}$ Ultrasonographic examinations were performed with the use of Voluson 730 Pro (GE Healthcare, Milwaukee, WI, USA). Transthoracic echocardiography was carried out on the first day after the delivery. Prenatal and postnatal echocardiography measurements were evaluated by pediatric cardiology and perinatology departments. Statistical analysis was done by SPSS v. 11.5 (SPSS, Inc., Chicago, IL, USA). Constant data were provided as median.

\section{Results}

Median week of gestation for the cases was 32 (range: 24 to 34) weeks when prenatal diagnosis was established. In the fetal ultrasonography during second trimester for the cases which were diagnosed at third trimester, the size of right ventricle was normal, and no abnormality was observed at the right ventricle outlet. Bipartite right ventricle cavity was found in cases diagnosed at second trimester, and tripartite right ventricle cavity in cases diagnosed at third trimester. No case developed pulmonary atresia. Median delivery week was 37 (range: 37 to 39 weeks) and median birth weight was 2950 (2570-3060) g. Two of the seven cases were monochorionic diamniotic twin pregnancy, and twinto-twin transfusion syndrome was not developed in either case. One of the twin pregnancies delivered at 37 
weeks of gestation while the other one at 34 weeks of gestation. Development of fetuses was normal in the twin pregnancy which delivered at 37 weeks of gestation; however, selective intrauterine growth retardation (IUGR) developed in the other twin pregnancy delivered at 34 weeks of gestation. While critical PS was observed in the elder fetus, there was perimembranous ventricular septal defect in the donor fetus. Chromosome examinations of all cases were normal; one case had anal atresia. Tricuspid valve $Z$-score of the cases with bipartite right ventricle morphology was less than those with tripartite. Also, in 5 cases with negative tricuspid valve $Z$-score, medium tricuspid failure was detected. Prostaglandin E1 (PGE1) infusion was initiated in all cases as soon as they were born. In 3 bipartite cases, cyanosis developed at early period despite the PGE1 infusion, and all had balloon valvuloplasty on postnatal second day. In one case, BT shunt was performed since cyanosis continued on 5th day after balloon valvuloplasty, no problem observed during 3month follow-up. Another case had operation due to anal atresia after valvuloplasty; when cyanosis increased after the operation, the case was referred for BT shunt but passed away when 15-day-old before shunt was applied. The other 37-week-old twin with bipartite morphology was applied BT shunt at the same day since sufficient clinical response was not received after balloon valvuloplasty. Clinical findings were stable during 3-month clinic follow-up. In four tripartite cases, cyanosis was kept under control better with PGE1 infu- sion; balloon valvuloplasty was applied in 3 cases on postnatal 2 nd week (9th, 11th and 12th day, respectively); also ductal stent was placed to one case (case nr. 6). Fourth case was monitored in the newborn intense care unit for 54 days by PGE1 treatment on receptor baby developing selective IUGR; and balloon valvuloplasty was applied on 55 th day (Table $\mathbf{1}$ ).

\section{Discussion}

Critical PS is a cardiac anomaly which is present at postnatal early period together with right ventricular hypoplasia and where pulmonary circulation depends on ductus. It requires postnatal emergency medical and invasive/surgical treatment. Therefore, diagnosing at prenatal period and delivering at a tertiary center are very significant in terms of applying prostoglandin E1 treatment at postnatal period without any delay and to make preparations for required procedures afterwards.

In our study, we aimed to discuss treatment methods applied at postnatal period according to the right ventricular morphologies of 7 cases which were diagnosed as critical PS during prenatal period. In cases where right ventricular outlet of fetal is congested or closed, it is the tricuspid valve size which determines the development level of right ventricle. ${ }^{[1]}$ The postnatal treatment planning of critical PS and PAIVS cases is determined according to tricuspid valve $Z$-scores. ${ }^{[6]}$ In compliance with the literature, we found that tricuspid valve $\mathrm{Z}$ scores of those with bipartite right ventricular morphol-

Table 1. Summary of the prenatal and postnatal data of 7 cases with critical pulmonary stenosis.

\begin{tabular}{|c|c|c|c|c|c|c|c|}
\hline Case & $\begin{array}{l}\text { Week of } \\
\text { gestation- } \\
\text { diagnosis }\end{array}$ & $\begin{array}{l}\text { Chromosomal/ } \\
\text { extra-cardiac } \\
\text { anomaly }\end{array}$ & $\begin{array}{l}\text { Week of gestation } \\
\text { and weight } \\
\text { (percentile) }\end{array}$ & $\begin{array}{c}\text { Cardiac } \\
\text { insufficiency, } \\
\text { hydrops }\end{array}$ & $\begin{array}{c}\text { Right } \\
\text { ventricle/ } \\
\text { component }\end{array}$ & $\begin{array}{c}\text { Tricuspid } \\
\text { insufficiency- } \\
\text { stenosis/Z-score }\end{array}$ & $\begin{array}{l}\text { Postnatal } \\
\text { treatment }\end{array}$ \\
\hline 1 & 25 & $\mathrm{n} / \mathrm{a}$ & $39-2950 \mathrm{~g}(10-50 p)$ & $\mathrm{n} / \mathrm{a}$ & Two & Exists-medium /-2.02 & $\begin{array}{l}\text { Balloon valvuloplasty on } 2 \text { nd day } \\
\text { BT shunt on 5th day - ALIVE }\end{array}$ \\
\hline 2 & 24 & Anal atresia & $37-2650 \mathrm{~g}(10-50 p)$ & $\mathrm{n} / \mathrm{a}$ & Two & Exists-medium /-2.05 & $\begin{array}{l}\text { Balloon valvuloplasty on } 2 \text { nd day } \\
\text { Exitus on } 15 \text { th day before BT shunt }\end{array}$ \\
\hline 3 & $\begin{array}{l}22 \text { MCDA } \\
\text { twin }\end{array}$ & $\mathrm{n} / \mathrm{a}$ & $37-2570 \mathrm{~g}(10-50 p)$ & $\mathrm{n} / \mathrm{a}$ & Two & Exists - medium/-2.65 & $\begin{array}{l}\text { Balloon valvuloplasty on } 2 \text { nd day } \\
\text { BT shunt on } 2 \text { nd day - ALIVE }\end{array}$ \\
\hline 4 & 36 & $\mathrm{n} / \mathrm{a}$ & $37-3000 \mathrm{~g}(10-50 p)$ & $\mathrm{n} / \mathrm{a}$ & Three & $\mathrm{n} / \mathrm{a} / 0.17$ & Balloon valvuloplasty on 9th day - ALIVE \\
\hline 5 & 34 & $\mathrm{n} / \mathrm{a}$ & $39-3060$ g (10-50p) & $\mathrm{n} / \mathrm{a}$ & Three & $\mathrm{n} / \mathrm{a} / 0.14$ & Balloon valvuloplasty on 11 th day - ALIVE \\
\hline 6 & 32 & $\mathrm{n} / \mathrm{a}$ & $38-2450 \mathrm{~g}(10-50 p)$ & $\mathrm{n} / \mathrm{a}$ & Three & Exists-mild /-0.49 & $\begin{array}{l}\text { Balloon valvuloplasty on } 12 \text { th day+ } \\
\text { ductal stent - ALIVE }\end{array}$ \\
\hline 7 & $\begin{array}{l}34 \text { MCDA } \\
\text { twin }\end{array}$ & $\mathrm{n} / \mathrm{a}$ & $34-3150$ g (50-95p) & $n / a$ & Three & Exists-mild /-0.65 & Balloon valvuloplasty on 55 th day - ALIVE \\
\hline
\end{tabular}


ogy were less than those with tripartite. ${ }^{[2,7-9]}$ Given the treatments applied during postnatal period, those with bipartite were required to have balloon valvuloplasty despite the prostaglandin treatment and also BT shunt was required since there was no sufficient recovery. Similar to our study, Cho et al. reported that BT shunt requirement was higher in those with bipartite right ventricular cavity among critical PS and PAIVS cases. ${ }^{[10]}$ Many studies highlighted that prenatal tricuspid valve sizes are significant to predict prognosis during postnatal period. ${ }^{[, 7-9]}$ The narrowing of tricuspid valve affects right ventricular development negatively while tricuspid valve deficiency affects right ventricular development positively. Therefore, in cases with high level of narrowing on tricuspid valve, the tricuspid valve deficiency is significant for the development of right ventricle. ${ }^{[1]}$ In our study, we found distinctive tricuspid valve deficiency in our 3 bipartite cases which had distinctive narrowing of tricuspid valve ( $Z$-score $<-2)$. It is considered that the tricuspid valve deficiency increases the volume load on right ventricle and supports the development of right ventricle. ${ }^{[1]}$ In cases having only narrowing on the tricuspid valve without any deficiency, it is possible to observe muscular pulmonary atresia as a result of the overgrowth of muscle layer on infundibular area. ${ }^{[1]}$ Similarly, Lowenthal et al. reported that postnatal prognosis was better in PAIVS and critical PS cases with mid- and severe deficiency on tricuspid valve. ${ }^{[7]}$

In monochorionic twin pregnancies, especially in twin-to-twin transfusion syndrome, the narrowing or atresia on the right ventricular outlet of the receptor fetus was higher than the normal population. ${ }^{[12-14]}$ In our two cases with monochorionic twin pregnancies, twin-to-twin transfusion syndrome did not develop. On the other hand, one case had selective IUGR and critical pulmonary stenosis was found in elder fetus. Similarly, Gardiner et al. reported in their series of 21 cases that there were 2 cases with monochorionic twin pregnancy which did not develop twin-to-twin transfusion syndrome. ${ }^{[2]}$ While we diagnosed one of our twin pregnancy cases at second trimester, we diagnosed other one at third trimester, and we did not found any cardiac pathology in second trimester ultrasonography. In the ultrasonographic screening at 18-22 weeks, right ventricle can be seen at relatively normal size, and therefore it can be overlooked. At the same time, the narrowing on right ventricular outlets displays progression and we are able to detect such patients at third trimester since hyperthrophy on right ventricle increases gradually. ${ }^{[1,1,16]}$

In cases with critical PS, chromosomal anomaly and extra cardiac anomaly are quite rare. Similarly, we found in our study no chromosomal anomaly, but anal atresia as extra cardiac anomaly only in one case. Generally, cardiac failure and intrauterine growth retardation are not observed during intrauterine period in cases with PAIVS and critical pulmonary stenosis. ${ }^{[1]}$ Correlatively, our cases did not develop any cardiac failure finding. Except the twin pregnancy with selective intrauterine growth retardation, we did not find intrauterine growth retardation in any of our cases.

\section{Conclusion}

Consequently, in critical PS cases, the treatment methods to be applied during postnatal period may vary according to the right ventricle being of two or three parts and the stenosis level of tricuspid valve. Therefore, diagnosing at prenatal period and categorizing cases will facilitate to maintain postnatal hemodynamic stability and to plan required invasive and/or surgical treatment options by initiating prostaglandin treatment.

Conflicts of Interest: No conflicts declared.

\section{References}

1. Yagel S, Silverman NH, Gembruch U. Fetal Cardiology: Embryology, Genetics, Physiology, Echocardiographic Evaluation, Diagnosis and Perinatal Management of Cardiac Diseases (Series in Maternal Fetal Medicine). 2nd ed. London: Informa Helatcare; 2008; p: 267-80.

2. Gardiner HM, Belmar C, Tulzer G, Barlow A, Pasquini L, Carvalho JS, et al. Morphologic and functional predictors of eventual circulation in the fetus with pulmonary atresia or critical pulmonary stenosis with intact septum. J Am Coll Cardiol 2008;51:1299-308.

3. Schneider C, McCrindle BW, Carvalho JS, Hornberger LK, McCarthy KP, Daubeney PE. Development of Z-scores for fetal cardiac dimensions from echocardiography. Ultrasound Obstet Gynecol 2005;26:599-605.

4. Bolger AF, Eigler NL, Maurer G. Quantifying valvular regurgitation. Limitations and inherent assumptions of Doppler techniques. Circulation 1988;78:1316-8.

5. Rivera JM, Vandervoort PM, Vazquez de Prada JA, Mele D, Karson TH, Morehead A, et al. Which physical factors determine tricuspid regurgitation jet area in the clinical setting? Am J Cardiol 1993;72:1305-9. 
6. Hanley FL, Sade RM, Blackstone EH, Kirklin JW, Freedom RM, Nanda NC. Outcomes in neonatal pulmonary atresia with intact ventricular septum. A multiinstitutional study. J Thorac Cardiovasc Surg 1993;105:406-23.

7. Lowenthal A, Lemley B, Kipps AK, Brook MM, MoonGrady AJ. Prenatal tricuspid valve size as a predictor of postnatal outcome in patients with severe pulmonary stenosis or pulmonary atresia with intact ventricular septum. Fetal Diagn Ther 2014;35:101-7.

8. Peterson RE, Levi DS, Williams RJ, Lai WW, Sklansky MS, Drant S. Echocardiographic predictors of outcome in fetuses with pulmonary atresia with intact ventricular septum. J Am Soc Echocardiogr 2006;19:1393-400.

9. Salvin JW1, McElhinney DB, Colan SD, Gauvreau K, del Nido PJ, Jenkins KJ, et al. Fetal tricuspid valve size and growth as predictors of outcome in pulmonary atresia with intact ventricular septum. Pediatrics 2006;118:e415-20.

10. Cho MJ, Ban KH, Kim MJ, Park JA, Lee HD. Catheterbased treatment in patients with critical pulmonary stenosis or pulmonary atresia with intact ventricular septum: a single institute experience with comparison between patients with and without additional procedure for pulmonary flow. Congenit Heart Dis 2013;8:440-9.
11. Davignon AL, Greenwold WE, Dushane JW, Edwards JE. Congenital pulmonary atresia with intact ventricular septum. Clinicopathologic correlation of two anatomic types. Am Heart J 1961;62:591-602.

12. Zosmer N, Bajoria R, Weiner E, Rigby M, Vaughan J, Fisk NM. Clinical and echographic features of in utero cardiac dysfunction in the recipient twin in twin-twin transfusion syndrome. Br Heart J 1994;72:74-9.

13. Lougheed J, Sinclair BG, Fung Kee Fung K, Bigras JL, Ryan $\mathrm{G}$, Smallhorn JF, et al. Acquired right ventricular outflow tract obstruction in the recipient twin in twin-twin transfusion syndrome. J Am Coll Cardiol 2001;38:1533-8.

14. Herberg U, Gross W, Bartmann P, Banek CS, Hecher K, Breuer J. Long term cardiac follow up of severe twin to twin transfusion syndrome after intrauterine laser coagulation. Heart 2006;92:95-100.

15. Todros T, Paladini D, Chiappa E, Russo MG, Gaglioti P, Pacileo G, et al. Pulmonary stenosis and atresia with intact ventricular septum during prenatal life. Ultrasound Obstet Gynecol 2003;21:228-33.

16. Paladini D, Volpe P. Ultrasound of Congenital Fetal Anomalies: Differential Diagnosis and Prognostic Indicators. 2nd ed. Boca Raton, FL: CRC Press; 2014; p: 184-6. 